Boise State University

ScholarWorks

Political Science Faculty Publications and

Presentations

Department of Political Science

3-1-2016

Campaigning for Capital: Fair Elections and Foreign Investment in Comparative Perspective

Michael Touchton

Boise State University 


\title{
Campaigning for Capital: Fair Elections and Foreign Investment in Comparative Perspective
}

\author{
Michael Touchton \\ Boise State University
}

\begin{abstract}
This paper addresses the question of what explains capital inflows. In so doing, it makes several contributions to the literature on political risk and the determinants of foreign investment. First, I clarify the relationship between capital flows and democracy's constituent parts in a way that takes arguments beyond aggregate democracy indicators and static political institutional structures. Specifically, I argue that fair elections signal government respect for democracy and the rule of law in a highly visible manner that investors can access. I show how investors use the fairness of elections as a way to assess political risk and to inform their investment strategies. Furthermore, I show how the type of investment and the kinds of evidence of electoral misbehavior condition elections' influence on capital flows.
\end{abstract}

I also disaggregate capital flows into foreign direct investment (FDI) and portfolio investment. I argue that the logic of investing is different in the short-term (portfolio) vs. the long-term (FDI). When it comes to political risk, I provide evidence according to which portfolio investment is much more sensitive to risk factors than FDI due to the relative ease with which portfolio investors can extricate themselves from an increasingly risky market and seek safer returns elsewhere.

Keywords: CPE, foreign direct investment, development, political risk, democracy

The ability to attract investments is a chief concern for many governments around the world. Governments seek to convince firms of the benefits of investing in their countries in order to generate revenue, jobs, technology transfers and increase competition in the marketplace. Similarly, firms seek to invest in countries whose political and economic comparative advantages allow them to minimize investment risk and maximize returns. An expanding pool of scholarship emphasizes the role of political institutions as indicators of political risk and thus as influential for channeling investment capital worldwide. For example, many studies highlight the importance of governments' credible commitments to property rights, contract enforcement and impartial treatment under the law for attracting investment (North and Weingast 1989; De Soto 2003; Keefer and Stasavage 2003; Glaeser, La Porta, Lopez de Silanes, and Shleifer 2004). Investors will not risk their capital and invest in a country if a government cannot credibly guarantee the safety of those investments. Firms will not buy land or build a factory if they fear that the state will nationalize their investment once it becomes profitable (Haber, Razo, and Maurer 2003; Hoff and Stiglitz 2002; North and Weingast 1989). Moreover, investors will be reluctant to make portfolio investments in a country if they fear the state will tax profits at confiscatory rates. Yet, firms' direct experience with property rights and contract enforcement are not the only factors investors consider when choosing where to invest. Human rights records (Blanton and Blanton 2012; 2007), political conflict (Braithwaite, Kucik, and Maves 2014), and political instability (Henisz, Mansfield, and Von Glinow 2010; Henisz and Zelner 2010) also carry great weight in investors' decisions because they can all signal political risk. ${ }^{1}$

This paper makes three central contributions to the literature on political risk and the determinants of capital inflows. First, it clarifies the relationship between capital flows and democracy's constituent parts in a way that takes arguments beyond aggregate democracy indicators and static political institutional structures. Specifically, I argue that fair elections signal government respect for democracy and the rule of law in a highly visible manner investors can access. Information, investors gain from the relative fairness of elections, fills the gap between obvious political risk due to violent conflict and obvious political security through complete commitment to the rule of law. I show how investors

\footnotetext{
${ }^{1}$ The literature on human rights and FDI also notes how human rights abuses can mobilize consumers against certain products and harm firms' profits (Blanton and Blanton 2012, 2007).
} 
This is an author-produced, peer-reviewed version of this article. The final, definitive version of this document can be found online at International Interactions: Empirical and Theoretical Research in International Relations, published by Routledge. Copyright restrictions may apply. doi: 10.1080/03050629.2016.1093475

use the fairness of elections as a way to assess political risk and to inform their investment strategies. Moreover, the type of investment and the kinds of evidence of electoral misbehavior, condition elections' influence on capital flows. This relationship is independent from broader measures of democracy, which are not statistically significant determinants of foreign investment in my models.

The second contribution is to disaggregate capital inflows into foreign direct investment (FDI), which has been studied extensively in relation to political risk and portfolio investment, which has garnered less attention. I argue that the logic of investing is different in the short-term (portfolio investment) vs. the long-term (FDI). Portfolio investment is more sensitive to political risk than FDI because of the relative ease with which portfolio investors can extricate themselves from an increasingly risky market and seek safer returns elsewhere. In contrast, FDI requires firms to commit to a country for a longer time frame if the firms are to realize investment gains because firms must buy land, build factories, train workers, connect or create infrastructure- all expensive start-up costs that increase the time before an investment will become profitable. Observers should therefore not expect temporary political risk to harm FDI, all things being equal, because firms pursuing long-term profits will only abandon their investments when the level of political risk is also consistently high over the long-term.

The third contribution is by drawing distinctions between visible evidence of unfair electoral behavior and public perceptions of electoral unfairness. Investment firms and individual investors do not make decisions to allocate capital lightly. Foreign investment may carry significantly more risk than domestic investment, especially when the former occurs in developing countries where investors' rights and the rule of law are not fully established. I argue that investors are careful to weigh political risk against investment reward when entering a country and are reluctant to depart once committed to an investment. Yet, capital still flows away from countries in political crisis as risk outweighs rewards and drives even loss-averse firms to abandon their investments. I present evidence according to which investors pay at least some attention to electoral signals in order to gauge the political risk associated with continuing their investments in a country. I also contend that investors distinguish between different types of electoral signals as they evaluate whether to drop their financial commitments in a country. I demonstrate that concrete evidence of unfair electoral behavior (for example, when the government jails opposition candidates, executives remain in office beyond constitutional term limits, police attack opposition party rallies) influences capital flows whereas general public perceptions of unfairness alone (there are concerns for electoral fairness in the national press, there are allegations of fraud after elections, there is international commentary about potential fraud) do not. This reflects investors' strong commitments to a country: investors have a high tolerance for political risk and only flee a country when presented with concrete evidence of public malfeasance (and thus clearer risk) as opposed to relatively opaque fraud claims stemming from accounts in the press that could be hearsay or conjecture.

I detail the relationship between elections and capital flows in the remainder of the paper, which proceeds as follows: First, I provide theoretical arguments for how political risk influences investment decisions and how the relative fairness of elections signals political risk. Next, I test my theoretical argument along with other popular theories against panel data on elections, FDI and portfolio investment for 178 countries from 1990-2013. Finally, I present the results of estimation and draw out the implications for investors and governments alike.

\section{Investment, Political Risk and Elections}

Investors devote capital to foreign investment in search of higher returns than domestic markets might offer. These higher returns frequently carry higher risk, which spurs investors to pay special attention to different aspects of politics that might alter the risk of doing business in a foreign country. Investors make different calculations when making decisions to invest directly (FDI) or through equities, bonds, currencies and other liquid assets (portfolio investment). First, FDI has a longer-term payoff and thus requires a longer-term investment outlook than portfolio investment. This is due to the high start-up costs required to build a factory, hire and train workers, purchase permits or incur other expenses in order to begin production. These FDI assets are relatively illiquid and recouping their purchase costs by devoting capital to different investments is difficult. Furthermore, FDI investment commitments can potentially last longer than their investment returns might suggest because of how investors treat sunk costs. Research in behavioral economics suggests that investors often hold onto assets with large sunk costs despite the prospect of additional losses in the future (Arkes and Blumer 1985; Arkes and Ayton 1999). This dynamic may be especially prevalent when the anticipated profits from FDI will not materialize for many years following the initial investment. For instance, an investment could be beset by cost overruns, the grabbing hand of the state and shifting market conditions, but investors escalate their commitment to the project because of the uncertainty surrounding future profits: the investment may 
This is an author-produced, peer-reviewed version of this article. The final, definitive version of this document can be found online at International Interactions: Empirical and Theoretical Research in International Relations, published by Routledge. Copyright restrictions may apply. doi: 10.1080/03050629.2016.1093475

still pay off in five years and the investors are averse to losing growing sunk costs in the meantime (Sleesman 2012; Winch 2013). The high start-up costs, loss-aversion and uncertainty associated with FDI, are therefore likely to produce long-term investment outlooks and thus long-term commitments to a country when investors devote capital to such projects.

Portfolio investment has relatively low start up costs compared to FDI. Buying shares in a foreign company or fund, foreign debt or currency requires no fixed investments in land, machinery or workers. Portfolio investment is also relatively liquid: divesting from portfolio investment in one country and transferring it to another is thus relatively easy. Portfolio investment is therefore likely to produce short-term investment outlooks and short-term commitments to a country relative to FDI. Of course, investors may still hold shares in a company or fund in defiance of market returns because of an aversion to losses and an unwillingness to treat costs as sunk (Elfenbein and Knott 2014; Lin, Fan, and, Chih 2014; Walia 2014). Still, exiting markets is likely to be easier for portfolio investors because they do not face the same high fixed start-up costs and illiquidity as foreign direct investors.

Market conditions determine much of investors' allocation and reallocation of capital among countries for both FDI and portfolio investment. For example, the cost of inputs to production in one country relative to another, the country's proximity to target markets, the interest rate on deposits in that country, and the country's rate of economic expansion are a few areas that influence return on investment and, in turn, investors' decisions. Political risk associated with investment, has also received considerable attention in scholarship on foreign investment (Braithwaite, Kucik, and Maves 2014; Henisz 2010; Henisz and Zelner 2010). Investors will not invest if they believe that their property will be confiscated or their profits taxed at confiscatory rates. Beyond property rights, political unrest in a host country is undesirable for the uncertainty it imparts to equity and bond markets, which harms portfolio investment. Political unrest is also undesirable for FDI because it disrupts market operations at the local level, where fixed investments are situated (transportation strikes, large protests, interrupted energy supply).

\section{Fair Elections as Political and Legal Bellwether}

The relative fairness of elections serves as an indicator for political unrest in general, and reflects politicians' respect for the law as well. Fair elections also act as potential proxies for the sanctity of property rights and legal contracts. Holding free and fair elections for public office represents a prerequisite of democratic governance and a fundamental, visible element of political practice (Schumpeter 1949; Dahl 1971; Zakaria 2007; Diamond 2001; Munck 2009). Free and fair elections can also influence investors' perceptions because they reveal valuable information about politicians' behavior in virtually all regime types- liberal democracies, illiberal democracies and autocracies- almost all of which now hold some type of elections. These elections are important for investment decisions because investors seek direct evidence of officials' stances toward the law before they trust politicians to protect their investments. For example, investors might hope politicians willing to respect electoral laws will also respect other laws and refrain from seizing property or enforcing contracts in their favor. Investors could put their faith in this imperfect proxy as information on how institutions channel political interests can be difficult to come by: political institutions are often complex and the total number of politicians in positions of power over investors is high. As a result, it may be difficult for even highly informed investors to build expectations surrounding property rights and contract enforcement based on institutional analysis or the political composition of government alone. Instead, free and fair elections are apparent to observers and demonstrate a minimum commitment to electoral laws. I contend that this visible commitment to public electoral law and fair play, may generate expectations of commitments to other laws as well. The relative fairness of elections may, therefore, also be important to investors as a bellwether of political risk.

Yet, simply holding elections is not enough to make politicians accountable, generate good governance and decrease political risk for investors. As Zakaria (2007) notes, governments that disrespect civil liberties and political rights often hold regular elections, but may alter or ignore the results, limit competition or otherwise minimize political accountability. These "illiberal democracies" cannot make credible policy commitments because the population has great difficulty punishing politicians for violating their commitments. The probability of politicians violating the rule of law then increases, as the threat of electoral reprisals for law-breaking decreases. Politicians who are not punished at the polls when they violate the rule of law, are likely to continue to violate it whenever its suits them. Private firms will therefore fear for their profits if the government does not respect the basic democratic right to fair elections because it shows that the government is not accountable to the law, may not uphold it and may also be vulnerable to opposition challenges. This type of assessment is increasingly important since the vast majority of countries now hold elections. 
This is an author-produced, peer-reviewed version of this article. The final, definitive version of this document can be found online at International Interactions: Empirical and Theoretical Research in International Relations, published by Routledge. Copyright restrictions may apply. doi: 10.1080/03050629.2016.1093475

The challenge facing investors in evaluating incomplete or illiberal democracies' levels of political risk and commitments to investors is particularly salient because many of the world's emerging markets feature governments that fall somewhere between consolidated democracies and authoritarian regimes on the democratic spectrum. It is relatively easy for investors to identify the high credibility associated with the rule of law in full democracies and low credibility in autocracies. In contrast, investors might have a tougher time evaluating political risk when a country's political landscape features a mix of new, but traditionally democratic institutions such as separation of political powers and checks and balances on the one hand and traditionally autocratic outcomes such as single-party dominance, low transparency and high corruption on the other. In such situations, I argue that a visible commitment to electoral law through fair elections may convince investors of a state's intentions toward private rights in a way political institutions alone will not. In short, investors need an example of new democratic institutions at work before they commit to investing in a market.

It is important to note that my argument is not necessarily that investors should use elections to infer a state's commitment to the law. In some cases this may be foolish- as when a myopic political leader follows a relatively fair election by seizing foreign portfolio investment that flows into the country as a result. It is also possible that a fair election brings to power a government that is committed to expropriation (such as Allende in Chile). The now-defeated incumbent's previous commitment to the rule of law, as signaled by his or her willingness to respect electoral laws and step down in the face of electoral defeat, is of little consolation for investors in this case. Politicians who step down after being defeated at the ballot box do not necessarily signal a state's commitments to uphold the rule of law and to protect investors' rights. Rather, my argument is only that investors use elections as a general proxy for political risk as elections are public and therefore visible. In particular, elections send valuable signals when governments are neither obviously trustworthy nor untrustworthy, as in many countries whose governments are neither consolidated democracies nor confirmed autocracies. Of course, not all fair elections will necessarily attract international capital: many factors beyond elections inform investors' decisions on where to send their money. I only contend that investors use evidence of electoral fairness as one proxy for respect for the law in other areas, such as property rights and political risk surrounding their investments. Capital may then flow into the country as a result of elections if new, more-credible assurances on property rights and contract enforcement tip investors' decision-making balance in favor of the country in question. The relative fairness of elections thus represents one of many factors influencing investors' decisions.

Fair elections do not occur in a vacuum: there are many specific political institutions that may increase or decrease the likelihood of fair elections and political risk (Henisz 2000; Persson and Tabellini 2003). My argument is not that elections are distinct from institutions. However, there are many different institutional configurations that can generate fair elections and signal government commitments to legal propriety. For instance, Great Britain, France and the Netherlands have broadly different means of translating votes into seats. Each country features different district sizes, different ways of selecting candidates to represent districts and different thresholds for gaining seats in the legislature, among many other differences. Yet all three countries are perceived to have fair elections. Most importantly here, all three European countries have far fairer elections than other countries with similar institutional forms. For example, Thailand's electoral rules match broadly with Great Britain's, Nigeria's pair well with France's on many dimensions and Ethiopia's are similar to Germany's. In these cases similar electoral rules are regularly associated with fair outcomes in one country and unfair outcomes in the other.

It is also important to note that unfair elections may actually be attractive to foreign investors. Unfair elections may signal political instability, but also certain characteristics of a country's government that might render foreign firms' property rights more secure, rather than less. First, regimes that routinely hold fraudulent elections might also be free to act without public oversight and make deals with foreign firms that secure their property rights over the objections of the citizenry or in ways that prevent competition (Touchton 2015). For example, an illiberal democratic government could offer a foreign energy firm a concession to extract oil and prevent public calls to nationalize such a firm from becoming reality by electing candidates that supported such a policy. In contrast, a democracy holding fair elections would find it easier to elect candidates that are committed to expropriation of foreign property, as discussed above. Second, firms may be able to secure extra-legal protections from powerful politicians or policymakers through bribes that generate greater security than the law would otherwise allow. In this scenario, a firm could seize productive land or mineral rights held by citizens with the help of corrupt officials. A country's legal system might be more likely to prevent such seizures in countries where electoral laws are also inviolate. Rather than serve citizens' interests, evidence of electoral misbehavior might also suggest that a government could be bought- a potentially desirable attribute for foreign firms. Finally, a regime that holds unfair elections may be signaling a commitment to remain in 
This is an author-produced, peer-reviewed version of this article. The final, definitive version of this document can be found online at International Interactions: Empirical and Theoretical Research in International Relations, published by Routledge. Copyright restrictions may apply. doi: 10.1080/03050629.2016.1093475

office over the objections of the populace. This may be attractive to foreign firms because it represents policy continuity, even as it might also simultaneously presage undesirable political unrest. In this last case, foreign investors may be ambivalent about unfair elections. Nevertheless, I argue that investors will be more likely to interpret unfair elections as signals of political instability and weak legal systems rather than opportunities to capture governments and secure rights through extra-legal means. This is because any property rights or contract enforceability secured outside of the law would be subject to the whims of the government, politicians or bureaucrats. Such promises are less credible than those made under a transparent, functioning legal system because there are fewer checks against the authority of public officials in the regime making illegal or extra-legal side deals with foreign firms. In these scenarios, there is little to prevent an authoritarian or illiberal government from seizing property at some future point when a firm is vulnerable following its initial investment (Olson 1993; North and Weingast 1989). The acknowledgement of the danger unconstrained leaders pose leads firms to associate greater political risk with investments in countries where governments routinely and publicly violate the law. This argument generates the following hypothesis:

H1: Foreign investment will be lower in countries where unfair elections are most prevalent.

I also argue that the logic of investment differs for portfolio investment and for FDI. Profiting from FDI requires a long-term commitment to operating within a country because of high start-up costs and fixed assets. Portfolio investment is relatively liquid by comparison and portfolio investors can exit a country's markets with fewer losses than foreign direct investors, all else equal. This assertion generates my second hypothesis:

\section{H2: Portfolio investment will be more sensitive to unfair elections than FDI.}

\section{Unfair Elections: Soft and Hard Evidence}

I argue that investors make an important distinction between general perceptions of electoral unfairness, which may stem from indirect evidence, and specific, visible examples of unfair electoral behavior. General perceptions of unfairness are less reliable than concrete evidence of legal violations, all else equal. This is because general perceptions of unfairness arise from press accounts (domestic and international), local protests, or popular dissatisfaction with electoral outcomes. Each of these sources of information may not be fully reliable. First, press accounts of unfairness may be biased against the regime in the case of opposition supported publications and thus present one-sided evidence or unfounded allegations of electoral unfairness in order to delegitimize the governing party and boost opposition parties. Second, opposition parties may organize election protests for the purpose of discrediting the governing party and gaining supporters. Paradoxically, the presence of opposition protests surrounding elections, may even signal the governing party's respect for the law even as the protests undermine perceptions of electoral fairness. This is because executives that violate electoral laws to stay in office may also be more likely to restrict public protests surrounding elections. As a result, public protests may even proxy for improvements in the rule of law- at least in countries that had not previously allowed freedom of speech and assembly. Finally, close elections or elections where a candidate gained office with less than a majority vote share might generate protests and allegations of unfairness due simply to popular dissatisfaction with the outcome, even if the election was primarily free and fair.

Investors have difficulty evaluating political risk through perceptions of electoral unfairness. Perceptions of unfairness may signal executives' disrespect for the law, and subsequently investors' rights, yet, they may also reflect media bias and dissatisfied publics. In contrast, interpreting direct, visible evidence of electoral unfairness is relatively straightforward. Investors do not have to weigh the odds of media bias or the presence of sore losers to know if the president has overstayed his or her constitutional term limit or if opposition leaders are in jail. These pieces of evidence demonstrate unfair electoral behavior clearly. As a result, I argue that investors will be more likely to flee countries whose governments engage in unfair electoral behavior compared to countries that only feature perceptions of unfair elections.

\section{H3: Unfair electoral behavior will influence investment flows more than perceptions of unfair behavior}

My point is that investors want to see if institutions work in practice, not just whether they exist on paper. I support this argument with evidence that unfair electoral behavior does influence capital flows. Portfolio investors remove their money from countries where they see concrete evidence of unfair elections. This suggests that even portfolio investment reflects at least a moderate commitment to a country's markets because weak evidence of electoral unfairness does not scare portfolio investors away. FDI is stickier due to the long-term commitments investors make 
This is an author-produced, peer-reviewed version of this article. The final, definitive version of this document can be found online at International Interactions: Empirical and Theoretical Research in International Relations, published by Routledge. Copyright restrictions may apply. doi: 10.1080/03050629.2016.1093475

to a country by virtue of investing in it. FDI is not sensitive to individual instances of unfair electoral behavior and instead, rises and falls with market conditions in the shorter term. Yet, FDI does rise in the presence of long-term commitments to fair elections, as measured by the time since unfair electoral behavior or unfair perceptions. This reflects the long-term commitments foreign direct investors must make to a country in order to realize investment profits.

The following section describes my dependent variables, portfolio and FDI inflows, along with several different measures of fair elections and the economic variables I use to model foreign investment flows.

\section{Variables and Methodology}

I divide capital flows into portfolio investment and FDI. The data is derived from the World Bank's World Development Indicators (2015). I collect annual data from 1990 to 2013, but then average this data over each country's electoral cycles. I also convert the data from current to constant (2010) dollars using the IMF's (2015) deflators and use the log of these data in my models of capital flows below.

\section{$\underline{\text { Fair Elections }}$}

My primary independent variables are several cross-national measures of how public officials behave surrounding elections and how the public perceives their behavior. First, I collect data from the National Elections Across Democracies and Autocracies (NELDA) database (Hyde and Marinov 2012). The NELDA project records information on a wide variety of perceptions, behaviors and outcomes surrounding national elections around the world from 19452010. Election-rounds, the unit of analysis, are included in the dataset provided the election is for a national political office (such as for a president or national legislative body, when elections are held to select a new parliament), the voters select a candidate from a ballot and that mass voting occurs. Election-rounds featuring only committee votes or other institutional votes result in an election's exclusion from the dataset (if the central committee of the governing party regularly elects the country's premier). NELDA includes every election meeting the criteria above- regardless of whether the election features enfranchised voters, competitive contests, electoral fraud or numerous legal violations. Other datasets do this as well, but the great value of the NELDA project relative to its competitors is Hyde and Marinov's meticulous collection of information describing the political context before and after elections in a countryparticularly with regard to an election's flaws. The NELDA dataset thus not only records information on whether the public, country-experts or other observers perceive an election to be unfair, but also collects data on politicians' behavior and electoral outcomes that might give scholars an idea of why the election might not be fair.

I use NELDA data to create two broad measures of unfair elections: a behavioral measure and a perceptual measure. The behavioral unfairness measure stems from the observed behavior of elected officials. The election-round scores for the behavioral unfairness variable are dichotomous and take on values of 0 or 1 . Country-rounds are coded as 1 , indicating behavioral unfairness, if any of the following conditions occurred surrounding elections in a country in a given year: the incumbent extended his or her term in office or eligibility to stand in elections beyond official term limits, specific opposition leaders were prevented from contesting elections, the government harassed the opposition by detaining leaders, using government forces to disrupt opposition rallies or shut down opposition newspapers. ${ }^{2}$

I record a score for each country-round, based on the country's experience in the most recent election-round preceding the annual measure of capital inflows, which I then average across the next election-round. There are 375 (out of 912) election-rounds in countries in the NELDA dataset where there is evidence of unfair behavior surrounding elections based on my aggregation of the individual NELDA components.

Next, I used NELDA data to create a measure of perceptual unfairness. It is coded 1, indicating public perception of unfair elections, if any of the following conditions held prior to or following the election in a given country-year: there is domestic or international concern that elections will not be free or fair, there are reports critical of the government's administration of the election that reach large numbers of people, there are riots or protests following elections based on allegations of vote fraud. Otherwise a country year is coded " 0 ". ${ }^{3}$ There are 403 (out of 912) election-rounds in the NELDA dataset where there is evidence the public perceived an election to be unfair.

${ }^{2}$ These areas correspond to NELDA variables 9, 13, 15, 31 and 32.

${ }^{3}$ This corresponds to NELDA variables 11, 28 and 30. 
This is an author-produced, peer-reviewed version of this article. The final, definitive version of this document can be found online at International Interactions: Empirical and Theoretical Research in International Relations, published by Routledge. Copyright restrictions may apply. doi: 10.1080/03050629.2016.1093475

\section{Control Variables}

I include several control variables in my models of capital inflows to test hypotheses on fair elections, market conditions and investment decisions. These variables help to isolate any potential independent role of fair elections from other political factors and concurrent shifts in economic factors that may also influence investment decisions.

\section{Regime Stability}

My first control variable records the time, in years, since a country experienced regime change (Beck, Clarke, Groff, Keefer, and Walsh 2001). The frequency of regime change is a proxy for political stability over the long-term, which influences market conditions and in turn, investment choices. Investors can assume that a country's politics are more stable as its system of government remains in place for a longer period of time. I argue that investors also assume that, on average, any agreements they make with the government will be more stable as the chance of regime change decreases. I test this hypothesis and control for regime stability's potential influence on foreign investment by including it in my models. ${ }^{4}$

\section{Democracy}

I include a control variable for the concept of democracy itself in the model. In contrast to democratic governments, authoritarian governments are likely to harm the rule of law (Maravall and Przeworski 2003), as are illiberal democracies (Zakaria 2007). However, several studies show that democracies may have little influence on investment, once property rights are taken into account (Sachs and Warner 1995). Moreover, high economic growth rates under authoritarian regimes in some East Asian and a few Latin American countries suggest these governments may identify ways to make credible commitments to property rights and contract enforcement without democratic constraints on authority (Gehlbach and Keefer 2011; Montinola, Qian, and Weingast 1995; Knack and Keefer 1995; Barros 2003). This raises the frequently-asked question of whether democratic practice maps onto investment and is worth examining in a global context. ${ }^{5}$

Freedom House assesses political rights in each country around the world, by collecting data on its electoral process, its levels of political participation and pluralism and on how well its government functions. FH ranks each country from 1 (most free) to 7 (least free) based on expert responses to 10 different questions (Freedom House 2013). This is a widely-used measure of de facto, rather than de jure democracy and thus it allows me to further evaluate my argument surrounding institutional function over form. The mean score for the countries in my dataset is 3.6 with a standard deviation of 1.4 .

\section{GDP per Capita}

I also estimate the relationship between a country's economic productivity and capital inflows. A country's relative productivity represents a key alternative explanation connecting high-functioning democracies with investment. Relationships between industrialized democracies and investment flows may only reflect underlying links between these countries' support for property rights and contract enforcement and their subsequent productivity. I account for this possibility by including a variable measuring countries' GDP in my models. I use the log of each state's per capita Gross Domestic Product for each year in the database adjusted for purchasing power parity. These figures are in constant 2011 dollars and come from the World Bank’s World Development Indicators (2015). ${ }^{6}$

\footnotetext{
${ }^{4}$ Regime stability is only correlated with the time since unfair electoral behavior variable at -0.09 and with the time since unfair perceptions variable at -0.08 . This low correlation reflects the longevity of illiberal regimes that suppress revolutionary dissent that might lead to regime change (and also hold unfair elections) as well as the longevity of liberal democratic regimes in the dataset. In other words, regime changes is rare at either end of the democratic spectrum, whereas unfair elections cluster at the low end of the democratic spectrum by definition.

${ }^{5}$ Freedom House Scores and unfair electoral indicators are correlated, but exhibit variance inflation factors less than 2 in my data. Multicollinearity between these variables is therefore not a serious concern for my models of foreign investment.

${ }^{6}$ I take the base 10 log of each observation and transform the variable so that it conforms to assumptions of normality for use in my regression models.
} 
This is an author-produced, peer-reviewed version of this article. The final, definitive version of this document can be found online at International Interactions: Empirical and Theoretical Research in International Relations, published by Routledge. Copyright restrictions may apply. doi: 10.1080/03050629.2016.1093475

\section{GDP Growth Rate}

This data comes from the World Bank's World Development Indicators (2015) and will likely correlate positively with FDI and portfolio inflows. Rapidly growing economies offer profitable investment opportunities whereas shrinking economies send investors fleeing to more profitable markets.

\section{Trade}

I measure trade as a country's annual imports plus exports divided by GDP. The data comes from the World Trade Organization (2015). I expect that countries engaged in greater trade will attract more FDI as well as portfolio investment because of their general support for imports and exports. Imports, such as factory machinery, are attractive to investors and architecture that supports exports is attractive to help bring the products built abroad to markets as well.

\section{Model Specification and Estimation}

I use fixed effects models to estimate the relationship between fair elections and investment flows. I estimate several models using different specifications and estimation techniques, but the primary models use cross-sectional, timeseries regression with fixed effects. Tables 1 and 2 below, present the results of estimation using this technique whereas the robustness checks section describes the complementary models. 
This is an author-produced, peer-reviewed version of this article. The final, definitive version of this document can be found online at International Interactions: Empirical and Theoretical Research in International Relations, published by Routledge. Copyright restrictions may apply. doi: 10.1080/03050629.2016.1093475

Table 1

Fixed Effects Estimates of Fair Elections and the Log of Portfolio Investment, 1990-2013. Investment is in Millions in Constant 2010 Dollars.

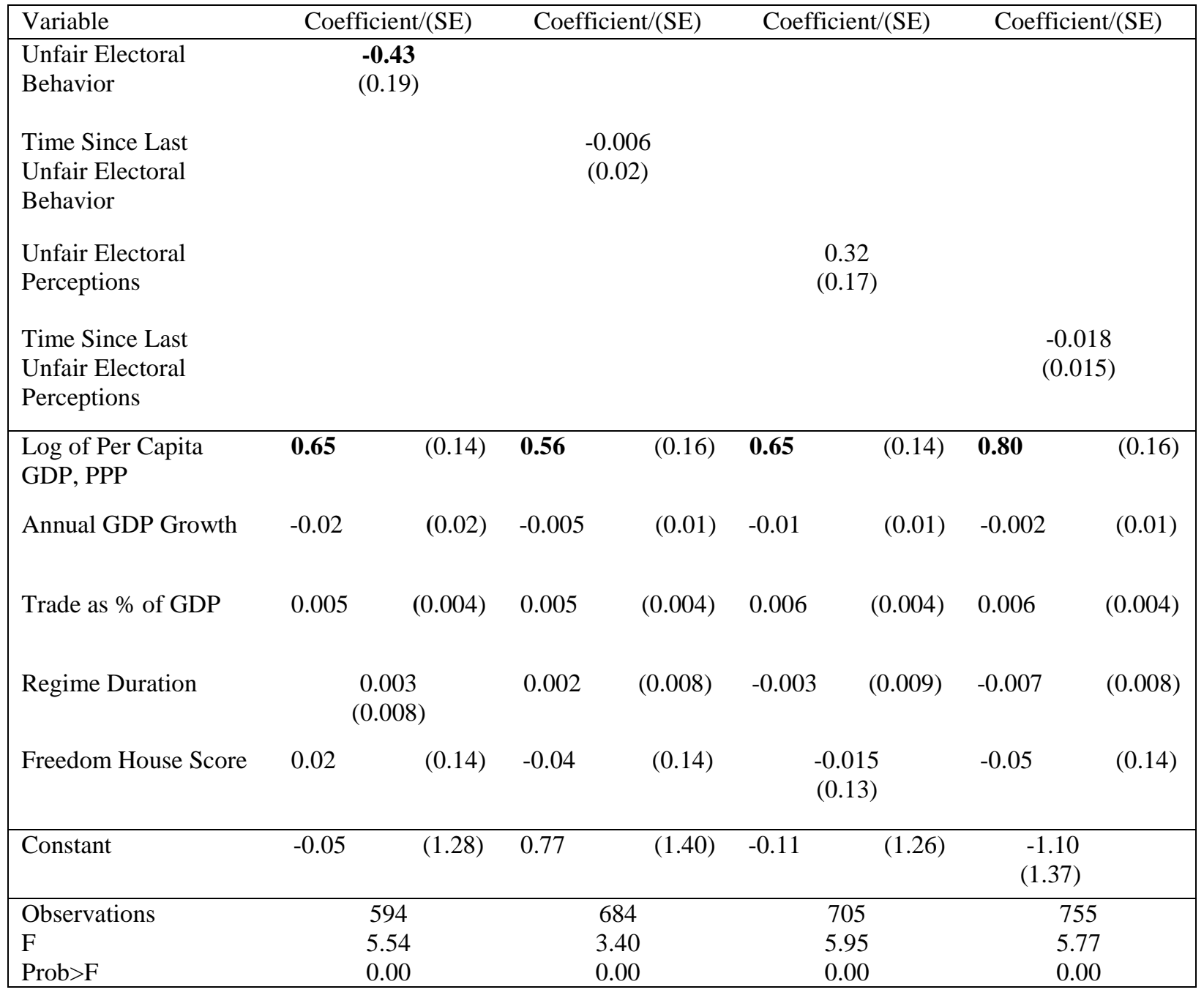

Coefficients in Bold are significant at $\mathrm{p}<.05$ 
This is an author-produced, peer-reviewed version of this article. The final, definitive version of this document can be found online at International Interactions: Empirical and Theoretical Research in International Relations, published by Routledge. Copyright restrictions may apply. doi: 10.1080/03050629.2016.1093475

Table 2

Fixed Effects Estimates of Fair Elections and log of FDI, 1990-2013. Investment is in Millions in Constant 2010 Dollars.

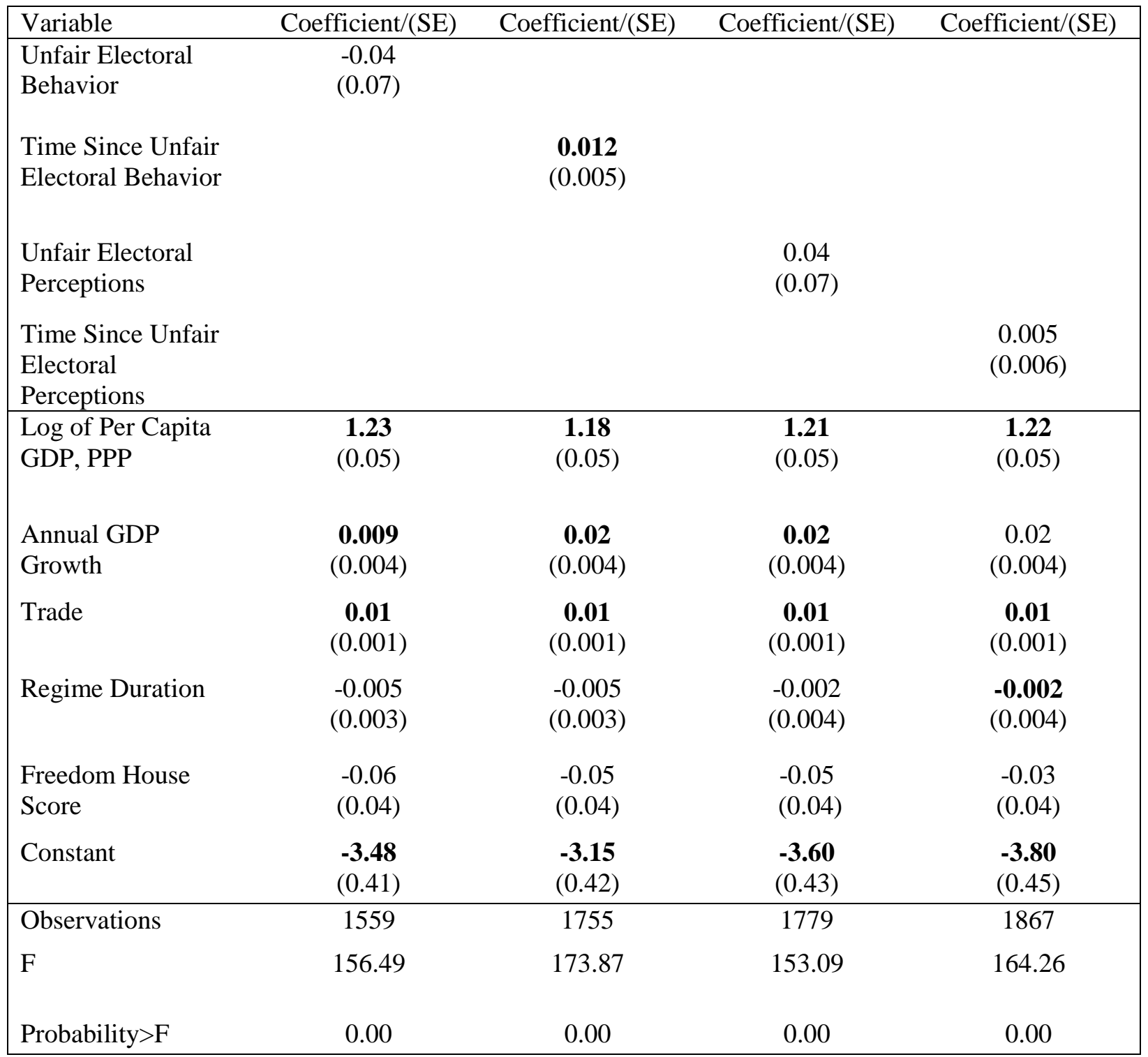

Coefficients in Bold are significant at $\mathrm{p}<.05$

\section{Results and Discussion}

Several different measures of electoral fairness have statistically significant connections with portfolio investment and FDI in my primary models. Evidence of unfair electoral behavior is associated with decreases in portfolio investment following unfair elections. Neither dichotomous measure of unfair electoral behavior or perceptions is statistically connected to FDI. I argue that this distinction is due to the reluctance of firms or investors to abandon their fixed investments in a country, even when evidence of electoral impropriety is overwhelming. This is likely due to the high costs firms incur surrounding their initial, long-term investment and the high cost of finding profitable investments in an alternate context. Abandoning future profits is simply not palatable unless the risk of expropriation increases dramatically following an unfair election. Political risk often does not change much following unfair elections because many unfair elections simply keep the incumbent government in power and maintain the status quo with regard to political risk. Long-term investors are more sensitive to regime instability, which represents potentially much higher 
This is an author-produced, peer-reviewed version of this article. The final, definitive version of this document can be found online at International Interactions: Empirical and Theoretical Research in International Relations, published by Routledge. Copyright restrictions may apply. doi: 10.1080/03050629.2016.1093475

political risk because regime change often carries with it a great risk of expropriation- especially for firms aligned with the ancien régime. By comparison, portfolio investors can pursue similar or better returns elsewhere and will likely lose fewer future profits by transferring their capital out of a country if political risk rises. Yet, portfolio investors are not as skittish as many governments fear: only concrete evidence of unfair electoral behavior is associated with decreased portfolio investment- perceptions of electoral unfairness alone are not statistically connected to portfolio flows. This result bodes poorly for a government's political opponents who may hope to use accusations of unfair elections to drive investment away from the country, generate political dissatisfaction and reap electoral benefits. My results suggest that on average, only clear evidence of unfair electoral behavior will scare portfolio investors away from a country's markets.

The estimated influence of unfair electoral behavior on portfolio investment is a decrease of \$2.69 billion USD per year following elections where unfair behavior occurred, holding all other variables in the model constant at their means. \$2.69 billion represents a tiny percentage of large economies' net annual portfolio investment, but $12 \%$ of mean annual portfolio investment for the country-years in my dataset and a huge percentage of portfolio investment for small economies. Sri Lanka's experience with elections and foreign investment provides a brief illustration of my argument. Sri Lanka's 2010 presidential election featured widespread examples of electoral fraud (Centre for Monitoring Election Violence 2010) and a long, violent aftermath where the government's violations of electoral law were common and highly visible. Portfolio investment decreased by $80 \%$ over this timeframe, from 2010 to 2012. In contrast, FDI was resilient to evidence of electoral fraud in Sri Lanka and even increased over the same timeframe. Other factors beyond elections clearly influence capital flows. The Sri Lankan example is only meant to illustrate how capital often flows away from a country when short-term, portfolio investors face clear evidence of unfair elections. Electoral unfairness generally does not faze direct investors, at least not in the short-term.

Next, I address the ways long-term commitments to fair elections can attract investment capital by signaling decreased political risk and building government credibility over time. I code two variables to measure commitment to fair elections: the first reflects data on the number of years since the previous instance of unfair electoral behavior, while the second records the number of years since unfair electoral perceptions based on NELDA data.

The results demonstrate the power of sustained fair elections over time for attracting FDI as well as the different timeframes governing FDI and portfolio investment. Consistently fair electoral behavior and perceptions are both associated with increased FDI. I estimate that each additional year of fair electoral behavior increases FDI levels by $\$ 110$ million USD. Moving from 1 year of fair electoral behavior to 10 years thus results in an estimated \$1.1 billion USD increase in FDI, ceteris parabus. However, on average, neither consistently fair electoral behavior nor perceptions influences portfolio investment. This reflects foreign direct investors' desire for long-term political stability in order to support their long-term profits compared to the short-term time horizon associated with portfolio investment. Portfolio investment is sensitive to political instability and market volatility in the short-term. However, portfolio investment may not remain in politically stable democracies for very long before re-entering more volatile, emerging markets that offer greater rates of return. There is therefore no statistical relationship between consistently fair elections and portfolio capital flows because portfolio investment regularly moves in and out of politically stable countries. Consistently fair elections may indeed reflect the political stability that facilitates the creation of capital for investment in the first place, but the lower risk premium associated with investing in these politically stable countries suggests that portfolio investors can often find greater returns elsewhere.

Several of the control variables I include in my models, are also statistically significant determinants of foreign investment. The size of a country's economy has a positive relationship with FDI in all of the models, but is not significantly connected to portfolio investment. There are no statistically significant connections between regime stability and capital flows in my models. The relative weight of trade in a country's economy is positively connected to FDI, but not to portfolio investment.

Finally, Freedom House democracy scores are not statistically connected to foreign investment. This is an important result, because it suggests that investors observe campaigns and elections at much greater rates than other aspects of democratic practice beyond elections. This corresponds to my argument that elections are visible representations of democratic performance, but also implies that other elements of democracy may be much harder to evaluate and therefore have less influence over investors' decisions. 


\section{Robustness Checks}

I use several alternative specifications and modeling techniques to assess the robustness of my results. First, I address the prospect of autocorrelation in the data by using first differences to estimate the relationship between fair elections and foreign investment in Table 1 (a) of the appendix (Baum 2006). ${ }^{7}$ Changes in unfair behavior are associated with changes in portfolio investment, but not FDI. Changes in perceptions of unfairness are not associated with changes in either portfolio investment or FDI. Next, I address the potential endogeneity problem associated with estimating the impact of fair elections on investment. In this case, countries' previous levels of foreign investment may influence the likelihood of holding fair elections in the first place. I therefore estimate several different models of portfolio investment and FDI to account for potential endogenous regressors. I use Arellano-Bond dynamic panel estimation to evaluate the relationship between fair elections and investment inflows in these models, which appear in Table 1 (b) of the appendix. ${ }^{8}$ These models use the "system" generalized method of moments (GMM) with one lag of the dependent variable. The instruments used are the behavior/perceptions indicators, the log of per capita GDP, annual rate of economic growth, the indicator for trade, the regime stability indicator, and the Freedom House score, beginning with the second lag and going back as far in time as the data exists for each variable. Coefficients for the fair elections indicators are generally larger in these models and the direction of the coefficients and the general levels of statistical significance are all similar to those in the primary models. ${ }^{9} \mathrm{I}$ use dummy variables for each year to ensure the assumption of no correlation across units holds. The results in Tables 1 (a) and (b) thus provide supporting evidence for Tables 1 and 2 and emphasize the strong connection between holding fair elections and capital inflows.

\section{Conclusion}

The results of my analysis provide evidence that investors evaluating political risk pay attention to the fairness of elections. Elections translate citizens' preferences into representative leadership and provide the means to hold politicians accountable. The fairness of elections can signal shifts in the probability of government propriety, respect for human rights (Blanton and Blanton 2012, 2007), political conflict (Braithwaite, Kucik, and Maves 2014) and general level of political stability (Henisz, Mansfield, and Von Glinow 2010; Henisz and Zelner 2010). Furthermore, elections function as a thermometer measuring a country's democratic health. Holding regular fair elections can assuage some fears of inconsistent, unconstrained rule and decrease uncertainty- independent of general economic trends within a country. But, elections' influence on investment flows depends on the nature of the investment itself. Portfolio investment is more sensitive than FDI to the short-term changes in political risk one unfair election signals. Even then, portfolio investment levels only fall when there is hard evidence of unfair electoral behavior, as opposed to public perceptions of unfairness alone. FDI is not sensitive to short-term changes in political risk, due to the longterm commitment FDI requires of investors. Instead, FDI levels are systematically higher in countries that hold consecutive fair elections over time and thus feature lower long-term political risk.

Leaders and governments can also learn from these results. Farsighted leaders will refrain from violating electoral laws, at least regularly and in visible ways, if they seek to attract more foreign direct investment. The corollary is that these same leaders can also get away with violating some electoral laws in the short-term and retain FDI- even if some portfolio investors flee the country's markets. This speaks to the nuanced nature of international capital flows: investors' vulnerability in the market conditions the way they interpret government signals and how or whether they act on them. The same actions that send portfolio investors fleeing to safer markets may not faze direct investors. My research thus shows the danger in treating all investment capital as identical and calls into question scholarship that aggregates all capital indicators without consideration of the different strategies investors in these areas use. My results also highlight the different types of evidence that investors use to gauge political risk. On average, neither portfolio nor foreign direct investors exit markets due to public perceptions and media reports of electoral unfairness. Instead, portfolio investors wait for clear, visible violations of electoral law before moving retrieving their capital from a country, while FDI does not budge in the face of unfair perceptions or behavior during one electoral cycle. These results run counter to some of the conventional wisdom surrounding investors' skittishness. Portfolio investors make

\footnotetext{
${ }^{7}$ The appendix is available online at my website: http://sps.boisestate.edu/politicalscience/faculty/mike-touchton/

${ }^{8}$ See Roodman, 2013 and Arellano and Bond 1988, 1991 for more information on this method.

${ }^{9}$ Both unfair electoral perceptions and behavior are significant predictors of portfolio investment in these models, while neither of the electoral variables are statistically significant determinants of FDI.
} 
This is an author-produced, peer-reviewed version of this article. The final, definitive version of this document can be found online at International Interactions: Empirical and Theoretical Research in International Relations, published by Routledge. Copyright restrictions may apply. doi: 10.1080/03050629.2016.1093475

financial commitments to markets and are reluctant to abandon those commitments without clear evidence of increasing political risk. FDI requires much greater commitments, and is therefore not sensitive to short-term concerns for political risk.

Finally, exhaustive scholarship ties democracy to development. Elections serve as another causal mechanism linking democratic practice to investment outcomes. ${ }^{10}$ One fair election increases portfolio investment, which can promote economic growth. Yet, one fair election does not matter for FDI. Consecutive fair elections increase FDI; an area with great potential for generating economic growth. But consistently fair elections are not statistically relevant for portfolio investment, which features a different timetable. The lesson here is that democracy and development may indeed be influential for one another, but not all of their constituent parts influence other parts in the same direction, or at the same time. Disaggregating both concepts reveals some of the nuance in their broader relationship. It thus also offers new opportunities to advance research in a way that can inform the drive for improving democracy and informing investment decisions around the world.

\section{Acknowledge}

I am grateful to two anonymous reviewers for their excellent suggestions during the review process. I am also indebted to my colleagues, who provided comments on earlier versions of this piece. Michael Allen and Brian Wampler deserve special recognition in this area.

\section{References}

Alesina, Alberto, and Stephen Spear. (1988) An Overlapping Generations Model of Electoral Competition. Journal of Public Economics 37 (3):359-37.

Andrews, Josephine, and Gabriela Montinola. (2004) Veto Players and the Rule of Law in Emerging Democracies. Comparative Political Studies 37(1):55-87.

Arellano, Manuel, and Stephen Bond. (1988) Dynamic Panel Data Estimation Using PPD: A Guide for Users. Institute for Fiscal Studies.

Arellano, Manuel, and Stephen Bond. (1991) Some Tests of Specification for Panel Data: Monte Carlo Evidence and an Application to Employment Equations. The Review of Economic Studies, 58(2):277-297.

Arkes, Hal, and Catherine Blumer. (1985) The Psychology of Sunk Cost. Organizational Behavior and Human Decision Process 35 (1):124-140.

Arkes, Hal, and Peter Ayton. (1999) The Sunk Cost and Concorde effects: Are Humans Less Rational Than Lower Animals?. Psychological Bulletin 125(5):591-600.

Barros, Robert. (2003) Dictatorship and the Rule of Law: Rules and Military Power in Pinochet's Chile. In Democracy and the Rule of Law, ed. J. M. Maravall and A. Przeworski. Cambridge: Cambridge University Press.

Baum, Christopher. (2006) An Introduction to Modern Econometrics Using Stata. Stata press.

Beck, Thorsten, George Clarke, Alberto Groff, Philip Keefer, and Patrick Walsh. (2001) New Tools in Comparative Political Economy: The Database of Political Institutions. The world bank economic review 15(1):165-176.

Biglaiser, Glen and Karl DeRouen, Jr. (2006) Economic Reforms and Inflows of Foreign Direct Investment in Latin America. Latin American Research Review 41(1):51-75.

Black, Duncan. (1957) The Theory of Committees and Elections. Cambridge: Cambridge University Press.

Black, David. (1999) The Long and Winding Road: International Norms and Domestic Political Change in South Africa. Cambridge Studies in International Relations 66 (1999):78-108.

Blanton, Robert and Shannon Blanton. (2012) Rights, Institutions and Foreign Direct Investment: An Empirical Assessment. Foreign Policy Analysis 8(4):431-451.

Blanton, Shannon, and Robert Blanton. (2007) What Attracts Foreign Investors? An Examination of Human Rights and Foreign Direct Investment. Journal of Politics 69 (1):143-155.

Blanton, Shannon, and Robert Blanton. (2009) A Sectoral Analysis of Human Rightsand FDI: Does Industry Type Matter? International Studies Quarterly 53(2):469-493.

Boix, Carles, and Susan Stokes. (2003) Endogenous Democratization. World Politics 55(04): 517-549.

Boix, Carles. (1999) Setting the Rules of the Game: The Choice of Electoral Systems in Advanced Democracies. The American Political Science Review, 93.3 (September 1999):609-624

${ }^{10}$ See Przeworski, Alvarez, Cheibub, and Limongi (2000), Boix and Stokes (2003) and Geddes (2003) among many others. 
This is an author-produced, peer-reviewed version of this article. The final, definitive version of this document can be found online at International Interactions: Empirical and Theoretical Research in International Relations, published by Routledge. Copyright restrictions may apply. doi: 10.1080/03050629.2016.1093475

Braithwaite, A., Kucik, J., \& Maves, J. (2014) The Costs of Domestic Political Unrest. International Studies Quarterly 58(3):489-500.

Branstetter, Lee, and Kamal Saggi. (2011) Intellectual Property Rights, Foreign Direct Investment and Industrial Development. The Economic Journal 121(555): 1161-1191.

Brown, David, Michael Touchton, and Andrew Whitford. (2011) Political Polarization as a Constraint on Corruption: A Cross-national Comparison. World Development 39(9): 1516-1529.

Busse, Matthias and Carsten Hefeker. (2007) Political Risk, Institutions and Foreign Direct Investment. European Journal of Political Economy 23 (2):397-415.

Buthe, Tim, and Helen Milner. (2008) The Politics of Foreign Direct into Developing Countries: Increasing FDI through International Trade Agreements? American Journal of Political Science 52 (4):41-762.

Centre for Monitoring Election Violence. (2010). Presidential Election 2010: Interim Report I. CMEV: Colombo.

Cheibub, Jose Antonio. (2007) Presidentialism, Parliamentarism and Democracy. New York: Cambridge University Press.

Chinn, Menzie, and Hiro Ito. (2008) A New Measure of Financial Openness. Journal of Comparative Policy Analysis: Research and Practice 10 (3): 309-322.

Dahl, Robert. (1971) Polyarchy. New Haven: Yale University Press.

Diamond, Larry. (2002) Elections Without Democracy: Thinking about Hybrid Regimes. Journal of Democracy 13(2):21-35.

Downs, Anthony. (1957) An Economic Theory of Democracy. New York: Harper \& Row.

Elfenbein, Daniel, and Anne Marie Knott. (2014). Time to Exit: Rational, Behavioral, and Organizational Delays. Strategic Management Journal (published online March 2014).

Geddes, Barbara. (2003) Paradigms and Sand Castles: Theory Building and Research Design in Comparative Politics. Ann Arbor: University of Michigan Press. 2003

Glaeser, Edward, Rafael La Porta, Florencio Lopez-de-Silanes, and Andrei Shleifer. (2004) Do institutions cause growth?. Journal of Economic Growth 9(3):271-303.

Haber, Stephen, Armando Razo, and Noel Maurer. (2003) The Politics of Property Rights: Political Instability, Credible Commitments and Economic Growth in Mexico, 1876-1929. New York: Cambridge University Press.

Henisz, Witold, Edward Mansfield, and Mary Ann Von Glinow. (2010) Conflict, Security, and Political Risk: International Business in Challenging Times. Journal of International Business Studies 41(5):759-764.

Henisz, Witold and Bennet Zelner. (2010) The Hidden Risks in Emerging Markets. Harvard Business Review 88(4):88-95.

Henisz, Witold. (2000) The Institutional Environment for Economic Growth. Economics \& Politics 12(1):1-31.

Hyde, Susan, and Nikolay Marinov. (2012) Which Elections Can Be Lost? Political Analysis 20(2):191-2010.

Jensen, Nathan. (2008) Political Risk, Democratic Institutions, and Foreign Direct Investment. The Journal of Politics 70(4):1040-1052.

Jensen, Nathan, Glen Biglaiser, Quan Li, Edmund Malesky, Pablo Pinto, Santiago Pinto, and Joseph Staats. (2012) Politics and Foreign Direct Investment. Ann Arbor: University of Michigan Press.

Knack, Stephen and Philip Keefer. (1995) Institutions and Economic Performance: Cross-Country Tests Using Alternative Institutional Measures. Economics and Politics 7(3):207- 227.

Li, Quan, and Adam Resnick. (2003) Reversal of Fortunes: Democratic Institutions and Foreign Direct Investment Inflows to Developing Countries. International Organization 57(1):175-212.

Lin, Yu-En, Whei-May Fan, and Hsiang Hsuan Chih. (2014) Throwing Good Money After Bad? The Impact of the Escalation of Commitment of Mutual Fund Managers on Fund Performance. Journal of Behavioral Finance 15(1):1-15.

Linz, Juan, and Arturo Valenzuela. (Eds.) (1994) The Failure of Presidential Democracy (Vol. 1). Baltimore: JHU Press.

Martinelli, Cesar, and Akihiko Matsui. (2002) Policy Reversals and Electoral Competition with Privately Informed Parties. Journal of Public Economic Theory 4(2002):29-61.

Mathur, Aparna, and Kartikeya Singh. (2013). Foreign Direct Investment, Corruption and Democracy. Applied Economics 45(8):991-1002.

Montinola, Gabriela, Yingyi Qian, and Barry Weingast. (1995) Federalism, Chinese Style: The Political Basis for Economic Success in China. World Politics 48(01):50-81.

Munck, Gerardo. (2009) Measuring Democracy. Baltimore: Johns Hopkins University Press

North, Douglass, and Barry Weingast. (1989) Constitutions and Commitment: Evolution of the Institutions of Public Choice in 17th Century England. Journal of Economic History 49(1):803-32. 
This is an author-produced, peer-reviewed version of this article. The final, definitive version of this document can be found online at International Interactions: Empirical and Theoretical Research in International Relations, published by Routledge. Copyright restrictions may apply. doi: 10.1080/03050629.2016.1093475

Olson, Mancur. (1993) Dictatorship, Democracy, and Development. American Political Science Review 87(03):567576.

Oneal, John. (1994) The Affinity of Foreign Investors for Authoritarian Regimes. Political Research Quarterly 47 (3):565-588.

Persson, Torsten, and Guido Tabellini. (2003) The Economic Effects of Constitutions. Cambridge: MIT Press.

Persson, Torsten and Guido Tabellini. (1990) Macroeconomic Policy, Credibility and Politics. New York: Harwood Academic Publishers.

Przeworski, Adam, Michael Alvarez, Jose Antonio Cheibub, and Fernando Limongi. (2000). Democracy and Development: Political Institutions and Well-being in The World, 1950-1990 (Vol. 3). New York: Cambridge University Press.

Rogoff, Kenneth, (1990) Equilibrium Political Budget Cycles. American Economic Review 80 (1990):21-36.

Rogoff, Kenneth, and Anne Sibert. (1988) Elections and Macroeconomic Policy Cycles. Review of Economic Studies 55(1988):1 -16.

Roodman, David. (2013) Xtabond2: Stata Module to Extend Xtabond Dynamic Panel Data Estimator. Statistical Software Components.

Roumanias, Costas. (2005) Signaling Through Political Campaigns: Elections as a Revelation Mechanism. Economics and Politics 17(2005):367-392

Schumpeter, Joseph. (1949) Capitalism, Socialism and Democracy. New York: Routledge.

Sleesman, Dustin, Donald Conlon, Gerry McNamara, and Jonathan Miles. (2012) Cleaning Up The Big Muddy: A Meta-analytic Review of the Determinants of Escalation of Commitment. Academy of Management Journal 55(3):541-562.

Svensson, Jakob. (1998) Investment, Property Rights and Political Instability: Theory and Evidence. European Economic Review 42 (7):1317-1341.

Touchton, Michael. (2015) Trapping the Tigers: The Regulation of Market Entry and the Rule of Law in SE Asia. The Social Science Journal 52(1):8-21.

Treisman, Daniel. (2000) The Causes of Corruption: A Cross-National Study. Journal of Public Economics 76(3):399457.

Tsebelis, George. (2002) Veto Players. Princeton, N.J.: Princeton University Press.

Walia, Bhavneet. (2014) The Home Mortgage Loan Crisis: A Lesson in Ignoring Sunk Costs. Journal of Management 15(2):31.

Winch, Graham. (2013). Escalation in Major Projects: Lessons from the Channel Fixed Link. International Journal of Project Management 31(5):724-734.

Zakaria, Fareed. (2007) The Future of Freedom: Illiberal Democracy at Home and Abroad. New York: W.W. Norton. 